\section{Birth of a Chimpanzee at the London Zoo}

THE birth of a chimpanzee, at the Gardens of the Zoological Society of London on February 15, is an event worthy of record; and it shows, in no uncertain way, how carefully the well-being of the great apes is studied at the Gardens. The mother, and her daughter, we are told, are doing well. Dr. Wyatt, of St. Thomas's Hospital, and Dr. G. M. Vevers, a member of the staff of the Society, missed no opportunity of studying all the phases of pregnancy, from the time that it was detected until the birth took place. The period of gestation was 250 days. The period of labour Dr. Wyatt describes as precisely similar to that of the human being. A detailed account of the birth is to be given in the next issue of the Proceedings of the Society. A deficiency of calcium being suspected, the prospective mother was given regular supplies of 'Micklefield irradiated milk'. This is prepared by passing fresh milk, in a thin film, under ultra-violet rays; a process which results in an increase of the vitamin D content of the milk; thus making the lime-salts in it more easily assimilated.

\section{Fertility of the Earth}

In his Research and Development Lecture delivered under the auspices of the Royal Institution and the British Science Guild at the Royal Institution on March 6, Sir Frederick Keeble spoke on the fertility of the earth. Soil-fertility is a product-a by-product of the bacteria and other microscopic forms of life that teem in incredible numbers in the soil. The crops grown in field and meadow serve mankind in two ways. On one hand, they supply substance for making blood, bone, flesh and sinew and for providing energy for the work of life. On the other hand, they supply substances which stir up the body to activity so that it can use the foods for building purposes and for supplies of energy. Therefore the most important task that agricultural science can accomplish is to discover and learn to control the conditions in which soil and crop provide both the necessary body-building and onergyyielding food materials and also those that stir up growth and activity in the animal and human body. Much is known of the conditions necessary for the production of the first kinds of food. But little is known about the conditions under which crops provide the growth-and activity-provoking foods. When this is understood, foods will be judged by a new and higher standard than they are at present; and with foods conforming to that standard, human strength will increase and health will improve.

\section{Maiden Castle, Dorchester}

Dr. R. E. Mortimer WheELER's account of his excavations at Maiden Castle, Dorchester, presented to the Society of Antiquaries of London on February 28, and his report in The Times of March 1, make possible a judicial estimate of the importance of this remarkable site in the prehistory of southwestern Britain on more assured evidence than size alone, impressive though this may be. As Dr.
Wheeler points out, Maiden Castle stands at the centre of an area noteworthy for the number of its sites of prehistoric occupation. It is clear that its history must be that of a pivotal point in cultural and social development. On the evidence afforded by the first season's exploration, four periods of occupation have been differentiated. Of these the earliest, surprisingly enough, was found to date back to the stone age - an occupation by a neolithic people, pastoralists, keeping sheep, pigs and a large breed of ox which had become extinct by historic times. They were pit-dwellers and makers of pottery of the 'Windmill Hill' type. This settlement is dated tentatively at 2,000 в.c. Of the later occupations two are pre- and one late-Roman. In the early Iron Age, towards its end, possibly about the fourth century B.c., a site of about fifteen acres was enclosed by ditch, rampart and palisade. The extension of the area to its present size of about a hundred acres, with its complicated series of defences, is perhaps to be attributed to the next period of settlement, but this is not yet clear. It was in this period in the second century в.c. that peoples from Brittany, with their Celtic craftsmanship, spread over the Somerset plain, reaching Glastonbury and Meare. At Maiden Castle, however, Dr. Wheeler has as yet discerned no funda. mental change in the character of the population. Towards the close of the period of Roman occupation the site, which for a time had been left derelict while the neighbouring Roman town of Dorchester was flourishing, was reoccupied and the building took place of the now famous Romano-British temple which Dr. Wheeler has rediscovered.

\section{Kalevala Centenary}

ON February 28, the Finnish people celebrated the centenary of the completion by Elias Lönnrott of the first edition of the Kalevala, the Finnish national folk-epic. The celebrations culminated in a great gathering in the recently completed Fair Hall at Helsingfors, at which a large number of scholars and delegates from foreign countries were present. Great Britain was represented by Mr. Robert Nichols, Dr. Margaret Murray (Royal Anthropological Institute) and Miss Agnes Dawson (Folk-Lore Society). It was at one time the fashion to compare the Kalevala with the Homeric poems ; but in fact this great collection of the legends and folk-lore of Finland is unique in European literature, both as a picture on an enormous canvas of a very primitive stage of society and as a mosaic of pagan magic, pagan religious belief and heroic legend. In this respect it surpasses anything that can be found in the pagan element of Germanic or Scandinavian saga. It consists of a large number of ballads which Lönnrott collected among the peasantry of Karelia, the eastern province of Finland, and wove into a composite whole. It has played an important part in fostering Finnish national aspirations, and has been a fertile source of inspiration in literature, art and music. Since Lönnrott's day much further material of a similar character has been collected. The esteem in which this body of literature is held as a national possession was marked in the 
present celebrations by a special session of the Diet at which a sum of approximately $£ 9,000$ was voted for the further study of the ancient history, culture and literature of the Finnish people, and by the presence of more than 4,000 people when M. Mamtere, Minister of Education, opened an exhibition, at which a large collection of pictures by Gallen Kalicia, Finland's greatest painter of Kalevala subjects, was the centre of attraction.

\section{Training the Industrial Chemist}

THE important subject of the training of an in. dustrial chemist was discussed by Mr. Thomas Donaldson in his address as chairman of the Glasgow Section of the Society of Chemical Industry at a meeting held jointly with the Glasgow Section of the Institute of Chemistry in the Royal Technical College, Glasgow, on March 1. Mr. Donaldson is general technical manager of the Explosives Group of Imperial Chemical Industries, Ltd., and though he made it clear that he was expressing his own personal opinions, his long industrial experience and his position as a governor of the Royal Technical College give him an opportunity of forming an unbiased opinion by being able to look at the problem from both sides. His chief criticism of the present system is that the training usually considered necessary to equip a man for chemical industry is too long. In Scottish universities a student of chemistry takes an honours degree requiring four years study and then normally pursues research leading to a doctorate. This research period extends over three years for a Ph.D. and then, at the age of about twenty-four years, the man endeavours to obtain an industrial position. Once in industry, it requires a further two years training before the man can be considered to be a thoroughly efficient member of his profession, since the university training has scarcely touched on industrial chemistry. Mr. Donaldson suggested that instead of the present system a man should take a three years pass degree, and he could then decide whether he would continue to pursue a technical career. If not, then, by two years training on the commercial side, he could become a thoroughly efficient technical salesman. If he decided to remain on the technical side he had two alternatives. $\mathrm{He}$ could complete his honours degree and do one year's post-graduate research, or he could take a two years course in applied chemistry. On this matter of starting research, Mr. Donaldson said that it is far more important that students should be trained in the methods of research rather than that they should solve any particular problem.

\section{Annual General Meeting of the Institute of Chemistry}

AT the fifty-seventh annual general meeting of the Institute of Chemistry held on March 1, Prof. Jocelyn Thorpe (president), in moving the adoption of the annual report, said that the register of the Institute now contains the names of 6,285 fellows and associates and more than 800 registered students. The Institute is in a strong position financially, and has co-operated with many other organisations in matters of public importance during the year. Negotiations are on foot for closer co-operation with other societies devoted to chemistry, particularly the Chemical Society and the Society of Chemical Industry. Continuing, Prof. Thorpe dealt with the importance of individualism in professional scientific life. Having regard to the bearing of the subject on the development of team work in research, he emphasised especially the desirability of giving due credit to the individual worker who initiated and developed ideas. He contrasted the present conditions for research work with those existing some forty years ago in the big German factories, where there was little or no intercourse between the members of the research section, who never seemed to talk to one another, being fearful lest they should communicate to their fellow-workers something of the investigations on which they had been engaged, and thus lose the credit due to themselves. This competitive method has now practically died out. The following were elected officers of the Institute for the ensuing year: President, Prof. Jocelyn Thorpe; Vice-Presidents, Mr. W. J. A. Butterfield, Sir George Clayton, Dr. A. E. Dunstan, Mr. F. G. Edmed, Dr. H. H. Hodgson, Mr. W. H. Roberts; Hon. Treasurer, Mr. P. H. Kirkaldy.

\section{Training in Food Technology}

In Nature of February 23, we summarised the proceedings at a meeting held under the auspices of the Food Group of the Society of Chemical Industry, to discuss a paper on this subject by Dr. H. B. Cronshaw, editor of Food Manufacture, the Manufacturing Chemist (not the Industrial Chemist, as erroneously stated in the notice), the Food Industries Weekly, etc. Dr. Cronshaw writes to us to make clear that he was advocating an extension, rather than a restriction, of the food chemist's general scientific training, particularly in pre-graduate days, in the direction of physical chemistry and of biology (including bacteriology); this is not in any way inconsistent with increased technological facilities, both in teaching and in research, at the post-graduate stage. $\mathrm{He}_{e}$ is in agreement with his fellow-members of the Food Group that the food technologist must be a scientific worker first and foremost.

\section{German Physical Congress}

THE Physikalische Zeitschrift of December 1, 1934, contains the communications and discussions made to the German Conference of Physics held in Pyrmont last September. The section on low temperatures includes reports on the magnetic method for attaining low temperatures, on supra-conductivity, on the calorimetric behaviour of metals at low temperatures, on reflection of light and photo-electric effect at low temperatures, etc. The other section on atomic and nuclear physics includes communications on absorption lines, discharge tubes, molecular oscillations in sound-wave phenomena, positrons, cosmic particles, and electron opties, etc. 